\title{
Bromoageliferin and dibromoageliferin, secondary metabolites from the marine sponge Agelas conifera, inhibit voltage-operated, but not store-operated calcium entry in PC12 cells
}

\author{
Ulf Bickmeyer* \\ Alfred-Wegener-Institut für Polar- und Meeresforschung in der Helmholtz-Gemeinschaft, Biologische Anstalt Helgoland, \\ Kurpromenade 201, D-27498 Helgoland, Germany
}

Received 8 November 2004; revised 23 December 2004; accepted 10 January 2005

\begin{abstract}
Two alkaloids isolated from the marine sponge Agelas conifera [Assmann, M., Köck, M., 2002. Bromosceptrin, an alkaloid from the marine sponge Agelas conifera. Z. Naturforsch. 57c, 157-160] were tested for interactions with cellular calcium homeostasis. Bromoageliferin and dibromoageliferin reduced voltage-dependent calcium entry in PC12 cells as measured with Fura II as calcium indicator. The half maximal concentration of both alkaloids to reduce voltage-dependent calcium entry was only slightly different: bromoageliferin showed a half maximal concentration of $6.61 \pm 0.33 \mu \mathrm{M}$, dibromoageliferin of $4.44 \pm 0.59 \mu \mathrm{M}$. Removal of calcium from extracellular solution for $10 \mathrm{~min}$ leads to an, at least, partial depletion of intracellular calcium stores, which induces a store-operated calcium entry after re-supplementation of calcium to the buffer. The store-operated calcium entry was unchanged by dibromoageliferin at a concentration of $30 \mu \mathrm{M}$, which fully blocks voltage-dependent calcium entry. The store-operated calcium entry induced by application of $5 \mu \mathrm{M}$ thapsigargin was similarly not altered by $30 \mu \mathrm{M}$ bromoageliferin. Both alkaloids reduce voltage-dependent calcium entry, but not storeoperated calcium entry. The inhibition of voltage-operated calcium entry by bromoageliferin is shown in whole-cell patch clamp experiments.
\end{abstract}

(C) 2005 Elsevier Ltd. All rights reserved.

Keywords: Secondary metabolite; Alkaloid; Calcium imaging; Voltage operated; Store operated; Calcium channel current; Capacitative

\section{Introduction}

As well as many other marine organisms, it is well documented that sponges produce interesting bioactive compounds. For example the genus Agelas (Agelasidae) contains a variety of bromopyrrole alkaloids (Braekman et al., 1992; Lindel et al., 2000) which have shown to be fish antifeedant metabolites within the tissue of Agelas sponges (Pawlik et al., 1995; Chanas et al., 1996; Assmann et al., $2000,2004)$. One of the possible cellular mechanisms of

\footnotetext{
* Tel.: +49 4725819 224; fax: +49 4725819283.

E-mail address: ubickmeyer@awi-bremerhaven.de
}

brominated alkaloids in their function as feeding deterrents has been investigated in a previous study, where bromopyrrole alkaloids were tested for interactions with the cellular calcium homeostasis. The investigated sponge metabolites interacted with cellular calcium signals, depending on the grade of bromination within in the pyrrole moitey of the molecules as well as the presence of an imidazole group. The alkaloids were also detected by tentacle ganglion neurons in the rhinophore of the sea slug Aplysia punctata underlining its potency as chemical signals (Bickmeyer et al., 2004).

Bromoageliferin and dibromoageliferin belong to the group of pyrrole alkaloids and are chemical relatives of the alkaloids sceptrin and dibromosceptrin, which inhibit 
voltage-dependent calcium entry (Bickmeyer et al., 2004). Therefore, I looked for effects of the two ageliferins on cellular calcium signals focusing on calcium entry via voltage-operated channels. Another calcium entry pathway, besides voltage-operated channels, is the store-operated calcium channel pathway, described in earlier literature as capacitative calcium entry (Putney, 1986). This type of channel is gated when intracellular calcium stores as the endoplasmic reticulum are depleted and need to be refilled. In the present study, the interaction of bromoageliferin and dibromoageliferin with both calcium entry pathways in the established cell line phaeochromocytoma PC12 was investigated.

\section{Material and methods}

\subsection{Experiments using PC12 cells}

\subsubsection{Culture methods}

PC12 cells from the DSMZ (German collection of microorganisms and cell cultures, Braunschweig, Germany) were kept in culture medium containing RPMI $1640,10 \%$ fetal calf serum, 5\% horse serum, and 100 units penicillin/streptomycin per $\mathrm{ml}$. Cells were cultivated in an incubator at $37{ }^{\circ} \mathrm{C}, 90 \%$ humidity and $5 \% \mathrm{CO}_{2}$. Cells were grown on collagen-coated cover slips and/or in collagen coated dishes. Cells were fed every 3 days and split when necessary.

\subsubsection{Fluorimetric measurements of intracellular calcium levels}

Cells were incubated with buffer (in mM: $125 \mathrm{NaCl}, 2.5$ $\mathrm{KCl}, 1 \mathrm{MgCl}_{2}, 2 \mathrm{CaCl}_{2}, 1.3 \mathrm{NaH}_{2} \mathrm{PO}_{4}, 30$ Glucose, $26 \mathrm{Na}$ HEPES) containing $5 \mu \mathrm{M}$ Fura II acetoxymethylester for $30 \mathrm{~min}$ at room temperature $\left(22 \pm 2{ }^{\circ} \mathrm{C}\right)$. The incubation buffer was removed and cells were washed for $20 \mathrm{~min}$. Fluorescence of cells was monitored by an imaging system (Visitron, Puchheim, Germany) and a CCD camera mounted on an inverted microscope (Zeiss Axiovert 100). About 30 PC12 cells were simultaneously measured, separated using 'the region of interest' function of the software (Metafluor, Meta Imaging Series). Fluorescence was obtained through an UV objective (Zeiss NeoFluar 20×). Data were obtained from division of two images, one obtained at $340 \mathrm{~nm}$, the other at $380 \mathrm{~nm}$ excitation. Fifty micromolar Fura II diluted in calcium buffer was used for determination of $R_{\max }$, buffer without $\mathrm{CaCl}_{2}$, but with additional $10 \mathrm{mM}$ EGTA for determination of $R_{\min }$ in calibration experiments. Fluorescence ratios were converted into calcium concentrations by the formula according to Grynkiewicz et al. (1985).

\subsubsection{Experimental design}

The recording chamber, mounted on an inverted microscope had a volume of $2 \mathrm{ml}$ and the peristaltic pump was adjusted to $3 \mathrm{ml} / \mathrm{min}$ exchanging the total chamber volume in less than a minute. To depolarize the cells, $80 \mathrm{mM} \mathrm{KCl}$ was used (supplemented for $80 \mathrm{mM} \mathrm{NaCl}$ ) in the experimental buffer. The depolarization of the cellular membrane potential thus increased gradually in less than a minute during perfusion. Cells were depolarized three times for 1 min during the course of a single experiment of about 60 min duration. Usually 30 cells were measured simultaneously. In another set of experiments cells were exposed to calcium free buffer $\left(\mathrm{CaCl}_{2}\right.$ removed and EGTA added) for 10 or more minutes to deplete intracellular stores, followed by re-supplementation of calcium leading to storeoperated calcium entry. During control experiments removal and re-supplementation of calcium for $10 \mathrm{~min}$ each gave reversible results for cellular calcium responses over up to four repetitive stimulations. In order to deplete intracellular calcium stores pharmacologically, $5 \mu \mathrm{M}$ thapsigargin was applied in the presence or absence of bromoand dibromoageliferin.

Results are presented as mean \pm SEM unless otherwise stated. Statistics and calculations were performed using computer software Prism (Graphpad) and Igor (WaveMetrics).

\subsubsection{Voltage clamp experiments using the whole cell configuration of the patch clamp technique}

Recordings were done using the EPC-7 patch clamp amplifier (List electronics) and analyzed with the computer program Signal 2 (CED). All experiments were carried out at day 1 or 2 after plating cells in collagen-coated dishes $(30 \mathrm{~mm})$. The bath solution contained: $135 \mathrm{mM}$ tetraethylammonium-chloride (TEA-Cl), $10 \mathrm{mM} \mathrm{N}$-(2-hydroxyethyl)piperazine- $N$-2-ethanesulfonic acid (HEPES), $1.2 \mathrm{mM} \mathrm{MgCl} 2,10 \mathrm{mM} \mathrm{BaCl}, 2 \mu \mathrm{M}$ tetrodotoxin (TTX) ( $\mathrm{pH}$ was adjusted to 7.2 with TEA-OH). Currents through calcium channels were recorded with patch pipettes of roughly $5 \mathrm{M} \Omega$ resistance. The pipette solution comprised: $135 \mathrm{mM} \mathrm{CsCl}, 10 \mathrm{mM}$ HEPES, $10 \mathrm{mM}$ ethylenglycol-bis(2-aminoethylether)- $N, N, N^{\prime}$-tetraaceticacid (EGTA), $2 \mathrm{mM}$ $\mathrm{MgCl}_{2}, 2 \mathrm{mM}$ Na-ATP (adjusted to pH 7.2 with TEA-OH). Calcium channel currents were evoked from a holding potential of -70 to $+10 \mathrm{mV}$ for $200 \mathrm{~ms}$ every $30 \mathrm{~ms}$.

\subsubsection{Sponge secondary metabolites and chemicals}

Purified sponge metabolites, bromoageliferin and dibromoageliferin (Fig. 1), were provided by Dr Michael Assmann (Alfred-Wegener-Institut für Polar- und Meeresforschung, AG Dr M. Köck, Bremenhaven, Germany). The compounds were isolated from the Caribbean sponge Agelas conifera using previously presented methods regarding collection, isolation and structural elucidation (Assmann et al., 2000; Assmann and Köck, 2002). Other chemicals were obtained from Sigma, Merck, Fluka and Molecular Probes. 
(a)

$$
\text { Bromoageliferin }
$$<smiles>Nc1ncc([C@H]2c3nc(N)[nH]c3C[C@H](CNC(=O)c3cc(Br)c[nH]3)C2CNC(=O)c2cc(Br)c(Br)[nH]2)[nH]1</smiles>

(b)
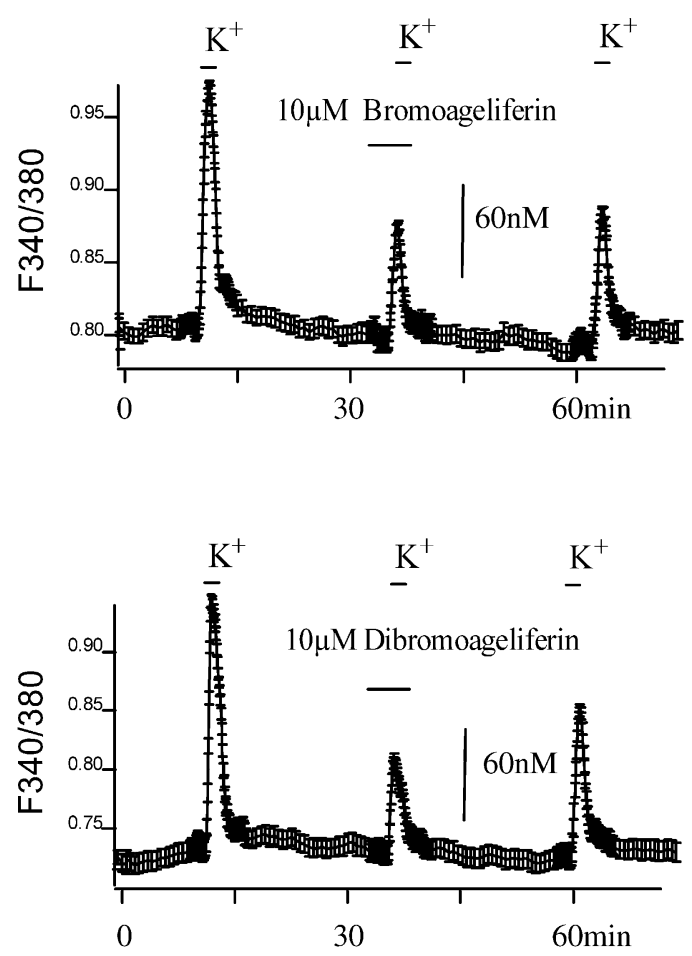

Dibromoageliferin<smiles>Nc1ncc([C@H]2c3nc(N)[nH]c3C[C@H](CNC(=O)c3cc(Br)c(Br)[nH]3)C2CNC(=O)c2cc(Br)c(Br)[nH]2)[nH]1</smiles>
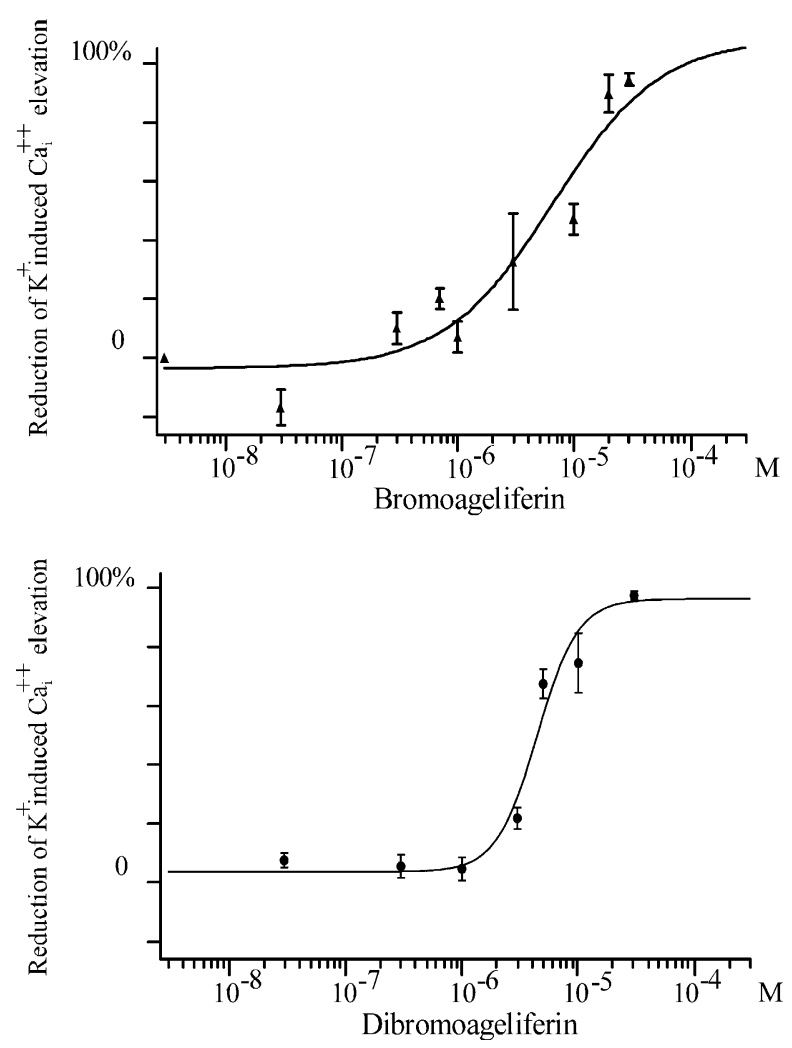

Fig. 1. (a) Chemical structures of bromoageliferin and dibromoageliferin. (b) Intracellular calcium levels $\left[\mathrm{Ca}_{i}^{++}\right]$, see scale bar, changes following depolarization with high potassium $\left(\mathrm{K}^{+}\right)$. Bromoageliferin and dibromoageliferin reduce voltage-dependent calcium elevations dose dependently. About 30 cells were measured simultaneously and the averaged traces are shown with bars representing SEM (left). The dose response relationship is calculated from 2 to 7 independent experiments for each concentration and fitted by the Hill equation.

\section{Results}

\subsection{Measurement of the depolarization induced calcium elevation in the presence of bromoageliferin or dibromoageliferin}

The pyrrole-imidazole alkaloid bromoageliferin contains three bromine atoms, whereas dibromoageliferin contains four bromine atoms, two in each pyrrole ring of the molecule (Fig. 1a). Both alkaloids fully prevent voltagedependent calcium elevation using a concentration of $30 \mu \mathrm{M}$ (Fig. 1b).

The additional bromine influenced the half maximal concentration of calcium entry blockade and the steepness of the dose response function (Fig. 3). Data were fitted by a Hill equation obtaining different fit parameters for the best description of results. Coefficient values \pm one standard deviation for bromoageliferin are: $x_{\text {half }}=6.61 \pm 0.45 \mu \mathrm{M}$ 
and the Hill coefficient $N=0.94 \pm 0.33$, for dibromoageliferin: $x_{\text {half }}=4.44 \pm 0.59 \mu \mathrm{M}$ and $N=2.49 \pm 0.82$ (Fig. 1). The effects of bromoageliferin and dibromoageliferin are hardly reversible by washout.

\subsection{Measurement of capacitative or store-operated calcium influx}

Removal of calcium from the extracellular solution for a period of $10 \mathrm{~min}$ leads to, at least, partial depletion of intracellular calcium stores. Following depletion of stores, a capacitative or store-operated calcium influx via storeoperated calcium channels is activated (Putney, 1986; Berridge, 1995; Koizumi and Inoue, 1998; Taylor and Peers, 1999). In the presence or absence of $30 \mu \mathrm{M}$ bromoageliferin and $30 \mu \mathrm{M}$ dibromoageliferin the calcium elevation was still present with a comparable amplitude (Fig. 2). The store-operated calcium entry can also be elicited by blockade of endoplasmic calcium ATPases using thapsigargin (Thastrup et al., 1990). The store-operated calcium entry induced by thapsigargin was similarly unchanged by bromoageliferin in the high concentration of $30 \mu \mathrm{M}$ (Fig. 3). This demonstrates the selectivity of both substances to block voltage-dependent, but not storeoperated calcium entry.

\subsection{Electrophysiological measurement of the blockade of voltage-operated calcium channels by bromoageliferin}

Whole-cell patch clamp recordings were carried out to prove that bromoageliferin blocks voltage-dependent calcium channels. Calcium ion channel currents were isolated by replacing sodium with TEA-Cl and additionally TTX to remove sodium currents and by TEA-Cl, cesium and barium to remove potassium currents. Barium was the charge carrier through calcium channels. Currents were elicited from a holding potential of $-70 \mathrm{mV}$ to various voltages (Fig. 3). Bromoageliferin (10-100 $\mu \mathrm{M})$ clearly blocked inward currents through voltage-dependent calcium channels. In order to measure calcium channel currents for more than $30 \mathrm{~min}$ without any 'rundown' of current amplitudes, a standard pipette solution with Na-ATP (Bickmeyer et al., 1993) was used. Fig. 3 shows original current traces and a current-voltage-relationship in the presence of bromoageliferin $(N=3)$. As additional information the time course of current blockade is demonstrated, indicating that after application of bromoageliferin it needs around 8 min until all currents are blocked. Bromoageliferin needs some time of incubation to develop its full effect. The current increase after application of a substance (see Fig. 3. time course) is probably related to the perturbation of the bath solution by application of substances and has been observed for several years and may originate in mechano-sensitive, barium-permeable ion channels (Weinsberg et al., 1994).

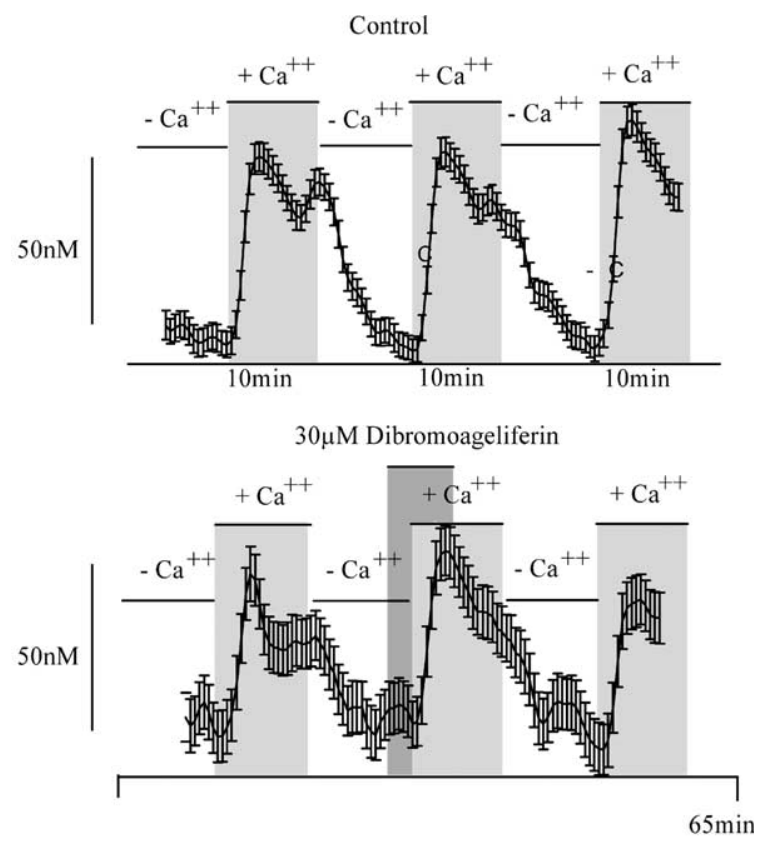

Calcium elevation induced by thapsigargin

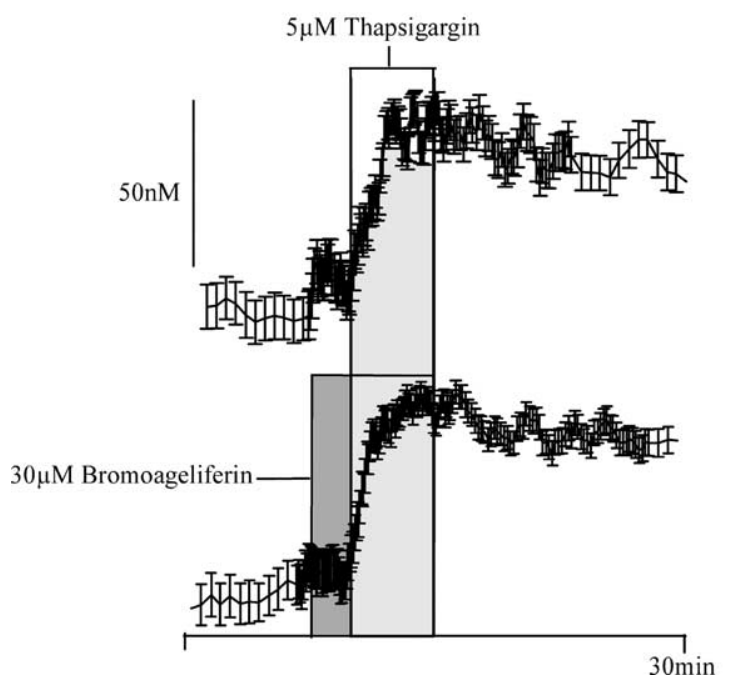

Fig. 2. Reduction of calcium elevation following re-supplementation of calcium to the buffer by bromoageliferin. Upper diagram shows $\left[\mathrm{Ca}_{i}^{++}\right]$responses (see scale bar) with threefold resupplementation of calcium, one with and without dibromoageliferin, following each $10 \mathrm{~min}$ of calcium removal. Lower diagram shows a $\left[\mathrm{Ca}_{i}^{++}\right]$response induced by $5 \mu \mathrm{M}$ thapsigargin with and without bromoageliferin. Experiments show data \pm SEM. All experiments were at least repeated twice.

\section{Discussion}

The pyrrole-imidazole alkaloids bromoageliferin and dibromoageliferin, isolated from the marine sponge A. conifera, interact with the cellular calcium homeostasis 

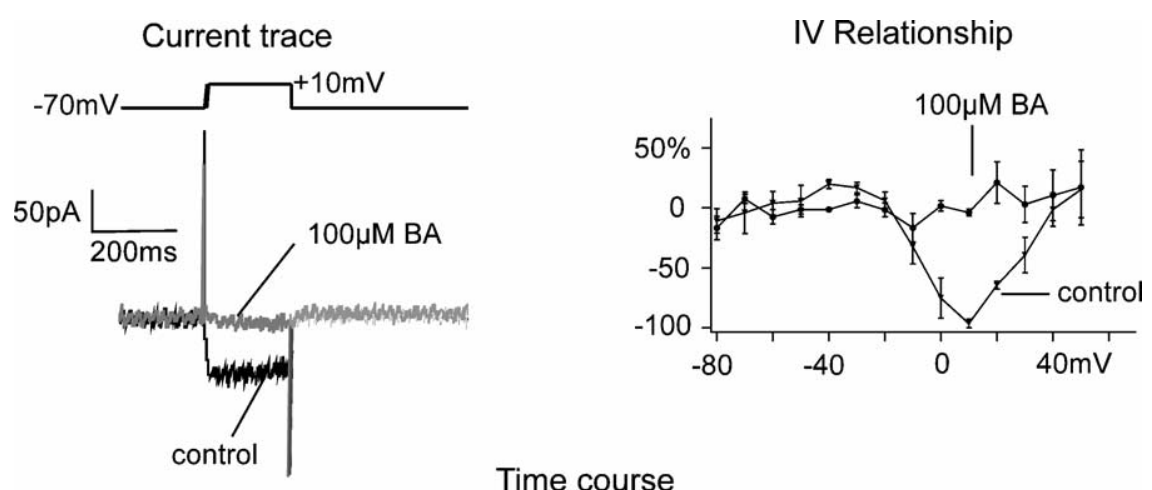

Time course

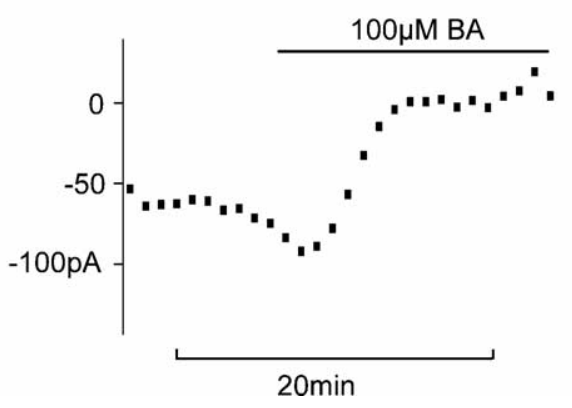

Fig. 3. Whole cell recordings of voltage-operated calcium channel currents. Original current trace with and without $100 \mu \mathrm{M}$ Bromoageliferin (BA). The current voltage relationship represent three independent recordings ( \pm SEM) with and without bromoageliferin, holding potential $-70 \mathrm{mV}$, stimulus to $+10 \mathrm{mV}(200 \mathrm{~ms})$. The time course shows current amplitudes elicited by voltage pulses $(-70$ to $+10 \mathrm{mV})$ every $30 \mathrm{~s}$.

by reducing voltage-dependent, but not store-operated calcium entry. Recently, several authors described that brominated alkaloids from marine organisms induce vasorelaxation or influence ionic membrane channels (Iwata et al., 2001; Peters et al., 2002; Bickmeyer et al., 2004). The potency of pyrrole alkaloids to inhibit voltage-dependent calcium elevation increased with the number of bromine atoms associated within the pyrrole moiety and with the presence of an imidazole group (present work, Bickmeyer et al., 2004). The pyrrole-imidazole alkaloids bromoageliferin and dibromoageliferin both reduce intracellular calcium elevations in a similar concentration range with a similar potency and half maximal concentration as dibromosceptrin. Sceptrin and oroidin have previously been described to have antimicrobial and cytotoxic effects (Bernan et al., 1993; König et al., 1998; Kelly et al., 2003) and to show anti-muscarinic activity (Rosa et al., 1992). The results may suggest that bromoageliferin and dibromoageliferin show a similar biological profile possibly based on impairment of cellular calcium signals. Interestingly, both brominated pyrrole-imidazole alkaloids showed no effect on store-operated calcium entry-underlining the specificity of the compounds to directly or indirectly inhibit voltage-dependent calcium entry. If a specific calcium channel subtype is a preferential target of an ageliferin alkaloid needs to be resolved, thus a slightly differential expression of calcium channel subtypes in cultivated cells may lead to scattered dose response curves.

\section{Acknowledgements}

I am grateful to Drs Michael Assmann and Matthias Köck (Alfred-Wegner-Institut für Polar- und Meeresforschung, Germany) for generously contributing purified bromoageliferin and dibromoageliferin. Many thanks to the students Ute Pullmann (BTA School Cologne, Germany), Janina Schäffner, Nicole Schwirrat (BTA School Hamburg, Germany) and Tim Migawski (University Oldenburg, Germany) for their sound help during the experiments. Many thanks to Prof. Dr Herbert Wiegand (Düsseldorf) for technical support. Drs Michael Assmann and Karen Wiltshire improved the manuscript with their suggestions.

\section{References}

Assmann, M., Köck, M., 2002. Bromosceptrin, an alkaloid from the marine sponge Agelas conifera. Z. Naturforsch. 57c, 157-160.

Assmann, M., Lichte, E., Pawlik, J.R., Köck, M., 2000. Chemical defenses of the Caribbean sponges Agelas wiedenmayeri and Agelas conifera. Mar. Ecol. Prog. Ser. 207, 255-262.

Assmann, M., Lichte, E., Köck, M., 2004. Multiple defensive roles for bromopyrrole alkaloids from Caribbean Agelas sponges. Proceedings of the Sixth International Sponge Conference, Rapallo, Italy, 2002. Boll. Mus. First Biol. Univ. Genova, vol. 68, pp. $187-193$. 
Bernan, V.S., Roll, D.M., Ireland, C.M., Greenstein, M., Maiese, W.M., Steinberg, D.A., 1993. A study on the mechanism of action of sceptrin, an antimicrobial agent isolated from the South Pacific sponge Agelas mauritiana. J. Antimicrob. Chemother. 32, 539-550.

Berridge, M.J., 1995. Capacitative calcium entry. Biochem. J. 312, $1-11$.

Bickmeyer, U., Müller, E., Wiegand, H., 1993. Development of neuronal calcium currents in a primary cell culture of the spinal cord and spinal ganglia. Neuroreport 4, 131-134.

Bickmeyer, U., Drechsler, C., Köck, M., Assmann, M., 2004. Brominated pyrrole alkaloids from marine Agelas sponges reduce depolarization-induced cellular calcium elevation. Toxicon 44, 45-51.

Braekman, J.C., Daloze, D., Stoller, C., van Soest, R.W.M., 1992. Chemotaxonomy of Agelas (Porifera: Demospongiae). Biochem. Syst. Ecol. 20, 417-431.

Chanas, B., Pawlik, J.R., Lindel, T., Fenical, W., 1996. Chemical defense of the Caribbean sponge Agelas clathrodes. J. Exp. Mar. Biol. Ecol. 208, 185-196.

Grynkiewicz, G., Poenie, M., Tsien, R.Y., 1985. A new generation of $\mathrm{Ca}^{2+}$ indicators with greatly improved fluorescence properties. J. Biol. Chem. 260, 3440-3450.

Iwata, S., Saito, S., Kon-ya, K., Shizuri, Y., Ohizumi, Y., 2001. Novel marine-derived halogen-containing gramine analogues induce vasorelaxation in isolated rat aorta. Eur. J. Pharmacol. 432, 63-70.

Kelly, S.R., Jensen, P.R., Henkel, T.R., Fenical, F., Pawlik, J.R., 2003. Effects of Caribbean sponge extracts on bacterial attachment. Aquat. Microb. Ecol. 31, 175-182.

Koizumi, S., Inoue, K., 1998. Functional coupling of secretion and capacitative calcium entry in PC12 cells. Biochem. Biophys. Res. Commun. 244, 293-297.
König, G.M., Wright, A.D., Linden, A., 1998. Antiplasmodial and cytotoxic metabolites from the Maltese sponge Agelas oroides. Planta Med. 64, 443-447.

Lindel, T., Hoffmann, H., Hochgürtel, M., Pawlik, J.R., 2000. Structure-activity relationship of inhibition of fish feeding by sponge-derived and synthetic pyrrole-imidazole alkaloids. J. Chem. Ecol. 26, 1477-1496.

Pawlik, J.R., Chanas, B., Toonen, R.J., Fenical, W., 1995. Defenses of Caribbean sponges against predatory reef fish I. Chemical deterrency. Mar. Ecol. Prog. Ser. 127, 183-194.

Peters, L., König, G.M., Terlau, H., Wright, A.D., 2002. Four new bromotryptamine derivatives from the marine bryozoan Flustra foliacea. J. Nat. Prod. 65, 1633-1637.

Putney, J.W., 1986. A model for receptor-regulated calcium entry. Cell Calcium 7, 1-12.

Rosa, R., Silva, W., Escalona de Motta, G., Rodriguez, A.D., Morales, J.J., 1992. Anti-muscarinic activity of a family of $\mathrm{C}_{11} \mathrm{~N}_{5}$ compounds isolated from Agelas sponges. Experientia 48, 857-885.

Taylor, S.C., Peers, C., 1999. Store-operated $\mathrm{Ca}^{2+}$ influx and voltage-gated $\mathrm{Ca}^{2+}$ channels coupled to exocytosis in pheochromocytome (PC12) cells. J. Neurochem. 73, 874-880.

Thastrup, O., Cullen, P.J., Drobak, B.K., Hanley, M.R., Dawson, A.P., 1990. Thapsigargin, a tumor promoter, discharges intracellular $\mathrm{Ca}$ stores by specific inhibition of the endoplasmic reticulum Ca-ATPase. Proc. Natl Acad. Sci. USA 87, 2466-2470.

Weinsberg, F., Bickmeyer, U., Müller, E., Wiegand, H., 1994. Barium permeable, mechanosensitive ion channels in bovine chromaffin cells? In: Elsner, N., Breer, H. (Eds.), Göttingen Neurobiology Report. Thieme Verlag Stuttgart, New York, p. 714 . 